\title{
ESSENTIAL ELEMENTS OF CHILDREN'S STORY BOOKS IN ISLAMIC PEDAGOGY BASED ON AL-QURAN TO CULTIVATE PROSOCIAL BEHAVIOUR AMONG PRESCHOOL CHILDREN
}

\author{
Ilyani Mohd Rosmadi ${ }^{1}$ \\ Early Childhood Education, \\ Faculty of Human Development, \\ Sultan Idris Education University, Malaysia \\ (Email: ilyanirosmadi@yahoo.com) \\ Zainiah Mohamed Isa ${ }^{2}$ \\ Early Childhood Education, \\ Faculty of Human Development, \\ Sultan Idris Education University, Malaysia \\ (Email: zainiah@fpm.upsi.edu.my)
}

Accepted date: 23-04-2019

Published date: 07-07-2019

To cite this document: Rosmadi, I. M., \& Isa, Z. M. (2019). Essential Elements of Children's Story Books in Islamic Pedagogy Based on Al-Quran to Cultivate Prosocial Behaviour Among Preschool Children. International Journal of Education, Psychology and Counseling, 4(31), 204-214.

DOI: $10.35631 /$ IJEPC.4310017

\begin{abstract}
It is a very concerning situation we are having today when seeing youngsters showing less involvement and not being helpful toward the ones in need. Having children to be exposed to storybooks is to introduce them with moral values that help in building their characters. Storybooks are developed containing pedagogies adapted from the Quran that convey the value of prosocial behaviour effectively. The pedagogies are narrative, dialogue, repetition and questioning. Typography, illustrations and simplified phrases are additional elements that are also included. This research involved 60 children aged 5 to 6 years old from selected preschools in Malaysia. 30 children are presented with the original version of the storybooks and the rest are presented with modified storybooks. Modified Prosocial Behaviour Questionnaire which consists of 15 items is required to be filled during pre and post-test. There was no significant difference on the pretest $(M=32.07, S D=3.89)$ and post-test $(M=32.80, S D=8.57)$ when using the original books; $t(29)=-0.427, p=0.672$ while there was a significant difference on the pretest $(M=23.83, S D=7.33)$ and post-test $(M-32.50, S D=7.93)$ when using the modified books; $t(29)=-16.478, p=0.000$.
\end{abstract}

Keywords: Prosocial Behaviour; Pedagogies from Quran; Modified Story Books

\section{Introduction}

Preschools include storytelling in their curriculum to implement the love for books. The main objectives of having the children to be exposed with storybooks are to help in building their 
literacy skills such as reading, enhance creativity through imaginations and also expose them with moral values that help in building their characters. This research will bring the spotlight to the moral values in a storybook itself. Prosocial behaviour is well known as an act with the intention of helping others (Cherry, 2017). It is due to the convenience of a child's environment at his or her preschool; surrounded by peers and teachers, in which the act of prosocial behaviour has a high possibility to happen when they are having classes, activities among groups and during play time. Prosocial behaviour is crucial to be taught and cultivated among children as it is one of the akhlaq (behaviour) that has been stressed on in Islam. Prosocial behaviour is being discussed among 5-year-old to 6-year-old children who are studying at preschools. It is believed that it will be effective to implement prosocial behaviour among the pre-schoolers through children's storybook.

The majority of scholars have the assumption that the psychological foundation for the development of prosocial behaviour is provided by cognitive and affective skills. For example, perspective taking, prosocial moral reasoning, adaptive attributional styles, perceived competence, and emotional well-being (Wentzel, 2015). Some other factors that contributed to the development of prosocial behaviour are genetic, temperament characteristics, and theoretical perspectives in the sense of environmental influences including parenting style; authoritative structure and also the interactions with peers. Knafo, Israel and Ebstein (2011) have put up an issue based on theoretical and empirical evidence that the development of children cannot only be explained by genes or by understanding children's behaviour. Storybooks are developed in this research which contains elements that would convey messages effectively from the storybooks using a story-telling method. It is focused on the pedagogies that are present in the Quran: narrative, dialogue, repetition and questions to be included in a children's storybook. These elements are anticipated in delivering the message or moral value among children through children's storybooks and for them to implement in everyday life. In addition, typography, illustration and simplified phrases are also included. Due to the popularity of fairy tales and the modern stories among children nowadays, it is a concern among the Muslims to see the young generations being unfamiliar about seerah (the stories of the prophets). The seerahs are full of positive teachings such as moral values. Therefore, the decision of making seerah as a medium of delivering the importance of having prosocial behaviour could bring the young generations to appreciate the Islamic stories.

\section{Problem Statement}

Researches have shown how vulnerable today's children toward immorality. According to People's Daily, youngsters today have no sense of respect toward the elders. They are involved in all kinds of anti-social behaviour that could bring danger to society (Ahmed Abba, 2014). It is doubted that future youngsters will be practicing prosocial behaviour in their lives without being taught and implemented during childhood. Stories from the Prophets' times are showing us on how to be kind and show mercy toward people around us. These stories show implementable acts of kindness by the Prophets themselves. Having the children to adore the Prophets and other Muslim figures in those times will help in many ways in building their characters and moral values. The aim of this research is to modify a published Islamic storybook into a book that contains Quranic and research-based of effective elements in cultivating prosocial behaviour among preschool children.

\section{Research Objectives}

This article elaborates on the essential elements that should be included in a children's storybook in which the elements are based on Islamic pedagogy in the Quran. The storybooks 
are then applied to preschool children to cultivate prosocial behaviour. Therefore, the objectives of this study are:

1. To identify the state of prosocial behaviour among children before reading the improved storybooks.

2. To identify the effective elements of a storybook in implementing prosocial behaviour among children.

3. To determine the effects of the improved storybooks on prosocial behaviour among children.

\section{Theories}

This study is based on the theory of development by Piaget in which children from five to nine years old will accept the rules that have been made by the authority figure and they also believe that any disobedience will lead to punishment (McLeod, 2015). On the other hand, Bukhari and Muslim narrated that Prophet Muhammad said: "Everyone is born with the basic innate nature which is inclined to submit to God; then his parents bring him up as a Jew or as a Christian or Magia" (Al-Bar \& Chamsi-Pasha, 2015). This proves that men are shaped as who they are today from how they have been brought up.

\section{Literature Review}

Academic performance and the development of cognitive competencies (e.g., problem-solving and moral reasoning) are also correlated with prosocial behaviour. It is also stated in the Quran about Allah's command in practicing prosocial behaviour in surah Al-Maidah verse 3: "Help you one another in righteousness and piety but help you not one another in sin and rancour" (Mohd Taib, Alias \& Mohd Taib, 2011). Starting from 4 years old until 7 years old, children learn to learn different perspectives other than from their own because children change from self-centered to people-centered. Russell (1994) stated that during this period of time, children not only understand fantasy stories but also more realistic stories in building a connection with people in order to build curiosity toward people and the world (Al-Somadi, 2012). Researches and theories supported the use of children's storybook in preparing them for social interaction (Al-Somadi, 2012). According to the Encyclopaedia on Early Childhood Development (2016), the development of prosocial behaviour is crucial during the early years as it is associated with social and emotional competence during childhood. For example; peer acceptance, selfconfidence, emotion regulation skills and also empathy.

Islamic teaching methods are based on the findings from the Quran and Hadith. Al-Khalediy (2011) has done research on the field of education as proposed by a Muslim, Burhan ad-Din/alIslam Az-Zarnooji in which had been developed in his book entitled Ta'lim al-Muta'llem-Tariq at-Ta'lham. According to the researcher, there have not been any studies on the subject of instruction. The Quran teaches the principles to conduct human's life and precept their behaviours toward the one and only God, fellowmen and the community. Preaching and advice are the basic methods found in the Quran. They have the most influence on children's development due to their sensitivity to preaching because they are still innocent in the heart. In addition, Muslims believe that storytelling is a way of inspiring and loving God and the Prophet (Rahim \& Rahiem, 2012). Ashaari (2011) has done an assessment of teaching and learning methodology in Islamic studies. The teaching method as have been practiced by Imam Abu Hanifah (699-767M), Imam Ghazzali (1058-1111M) and Ibnu Rushd (1126-1198M) could be applied in improving the Islamic studies. As in teaching Hadith, it should not only be theoretically and reading of the texts but should include contemporary rational and critical thinking. 
Narrative or storytelling is one of the elements that is included in this research. Her Majesty, Al-Abdullah (2010) connoted from her own written children literature, "The Sandwich Swap", that children's literature could implement way more than only teaching literacy and numbers among children at kindergarten stage (Al-Somadi, 2012). The aims of storytelling in the Quran is for 'ibrah (admonition, lesson). It is stated in the Quran in surah Yusuf verse 111: "there is, in their stories, lessons for men endued with understanding. It is not a tale invented, but a confirmation of what went before it, a detailed exposition of all things, and a guide and a mercy to a people who believe" (Kabir, 2013). Lee et al. (2014), have stated in their research that although classical moral stories have broadly been used, there is still no documentation stating whether such stories do implement honesty among children.

Dialogue is one of the prominent methods used during teaching and learning sessions in preschools. A research done by Zarasi and Ramchahi (2014) have discussed the themes and questions which are fundamental in evaluating the dialogue happened between Allah and Iblis. The dialogue was examined on the structure and features and focused on the composition and form, fundamental principles and characteristics of the dialogue. The dialogue is very informative and subtle, and it has brought to some important issues such as the history, vicissitude, personality and destiny of Iblis. The dialogue method has been practiced by medieval Muslim teachers through conversing with the pupils by asking questions to draw their attention and trigger their intellect (Al-Khalediy, 2011).

As we could see, nursery rhymes that are taught to the children contain repetition. They have discovered that the repetitions happened to highlight the crucial material and also to emphasize learning. Repetition must be practiced in preaching as the Prophet had repeated thrice in his words (Al-Khalediy, 2011). The repetition in surah Al-Baqara had been studied by El-Tahry (2010). A rhetorical device which consists of a repeated word or phrase placed near to the opening and end of a passage is known as inclusio.12 studies were done on 5299 preschoolers by the researchers at the Center of Early Literacy Learning (CELL) (2013) in evaluating the relevance between children's nursery rhyme abilities (experience, awareness, and knowledge) and their development in literacy skills. It was found that nursery rhyme experiences, awareness, and knowledge are certainly related to achievement in early phonological and printrelated skills.

Having dialogues between two sides; teachers and students, would encourage questions to arise. Questioning among children will enhance critical thinking and self-reflection. Higher Order Thinking Skills (HOTS) was suggested by Almenoar (2014) in the study by using Quranic verses in English. One of the objectives of the lesson by using HOTS is to build the students' background knowledge. It is done by bringing the focus to the positive effects of reflection and discipline because Allah exists. In a case study by Bay and K. Hartman (2015) involved two preschool teachers in knowing what type of questions they ask during activities with children. The results gained indicated that the teachers asked questions mostly on knowledge level (82.6\% and 69.4\%) and closed-ended questions (86\% and 92.2\%).

Suitable typography may help the children to be much interested in reading the book and to understand better the values and content presented. According to Tinker (1968), inter-character spacing, typographic parameters of font size, word spacing, line spacing, line length and justification do affect the performance in reading (Wilkins, Cleave, Grayson and Wilson, 2009). The Speed and Capacity of Language-Processing Test (SCOLP; Baddeley, Emslie \& Nimmo- 
Smith, 1992) was used and the prepared sentences were printed in the height of $4.2 \mathrm{~mm}$ (small text) and $5.0 \mathrm{~mm}$ (large text) in Arial font. The result gained was that the children verified the sentences $9 \%$ more quickly when presented with the larger typeface with $\mathrm{t}(23)=3.69, p<.001$. Two passages were in Sassoon Primary and the other two passages were in Verdana. It was found that the visual search speed in Sassoon Primary was 1.72 words per second while 2.46 words per second for Verdana.

Pictures or illustrations are believed to have a big impact on the interest of children toward storybooks. In the case of Islamic characters, some are forbidden to be drawn or illustrated due to religious affairs. Children in our society foresee to experience pictures and also images in relatively everything that they encounter (Nicholas, 2007). Meibauer and Meibauer (2013) have found that joint picture book reading encourages verbal interaction and build a strong connection of early book usage and later skills in reading and writing (Hall; Jones: Ninio and Bruner 4-10; Snow and Goldfiled 560; Whitehead 25-30). The children will understand more about what the story is about if pictures or illustrations related to the story are included.

Children do not understand certain words or phrases like adults. In keeping the interest in reading a book, the phrases need to be easily read by them. Subramaniam (2000) had done an observation of 32 Malay children to see their language acquisition. In acquiring the noun words depend on the vocabulary that they always use at home. O'Grady (2007) believed that children occupied language very quickly in which they could learn 10 words per day when they are between two to six years old.

\section{Methodology}

A pretest-post-test experimental design has been chosen in order to recognize the difference that will or will not happen on the state of prosocial behaviour among the children. Children were first recorded on their current state of prosocial behaviour by their respective teachers. Then, the children are exposed to the modified story books by reading to them. One storybook is read to the children twice per week which makes it five consecutive weeks for five books to be read. The teachers then recorded their scores on prosocial behaviour by using the Modified Prosocial Behaviour Questionnaire. The data is analyzed by the end of the experiment.

Table 1: Demographic Information Of Participants

\begin{tabular}{ccc}
\hline Characteristics & $\mathrm{n}=60$ \\
\hline Age (years) & 5 years old & $32(53.3 \%)$ \\
& 6 years old & $28(46.7 \%)$ \\
Gender (n) & Male & $30(50.0 \%)$ \\
& Female & $30(50.0 \%)$ \\
\hline
\end{tabular}

\section{Materials}

An Islamic based storybook entitled "Kisah Tauladan Islam" by Khan (2017) is chosen to be modified by including the elements. The book contains a number of Islamic stories. Five stories have been chosen from the original book which then was printed into five different books for each story. The first story is entitled "Malaikat dan Tiga Orang Lelaki" (Angel and Three Men). From this story, the children learned to be kind and helpful to each other. They are encouraged to share their things with others and not to lie to anyone. The second story entitled "Batu Beralih" (Moving Rock) is about three men who got stuck in a cave that is blocked by a huge 
rock. The story also teaches children to give a hand to anyone that needs their help. A story titled "Kisah dan Ajaran Nabi Muhammad" (Story and Teachings of Prophet Muhammad) tells about how the Prophet Muhammad received his first revelation from Allah when he was alone in a cave. This story actually teaches children to have sympathy toward the ones that are in need of help. Other than that, it also shows them to be kind to others. The fourth story chosen from the book is "Bertemu dengan Raja Najashi" (Meeting with King Najashi). This story actually shows the children to help each other in a group in achieving a goal. It also teaches the children to be kind and helpful to each other. The final story entitled "Keajaiban Semangkuk Susu" (The Wonder of a Bowl of Milk) shows the children to be patient and togetherness. They need to take turns when using things or when playing as how the people in the story take turns in drinking a bowl of milk.

In this research, global prosocial behaviour is being measured as it assesses personal tendencies in exhibiting a few prosocial behaviours across contexts and motives (Carlo \& Randall, 2002). The Modified Prosocial Behaviour Questionnaire (mod-PBQ: Weir \& Duveen, 1981- adapted by Doescher, 1986) found from research by Elizabeth Vale (2000) is applied in assessing a child's prosocial behaviour. The questionnaire consists of 15 items in which each item describes prosocial actions regularly shown by preschool children (Sugawara \& Burt, 1999). The questionnaire yields four distinct scores for each child which includes a total prosocial score, ranging from 15 to 45 points and three subscale scores, inclusive of cooperating, helping and sharing. Each is ranged from 5 to 15 points. As in the current research, it is only focused on the total prosocial score. The original version of Prosocial Behaviour Questionnaire (PBQ) consisted of 20 items. A test-retest reliability coefficient of .91 was attained while the interrater reliability coefficient was moderate at .66 . The mod-PBQ was adapted in pertaining to preschool children due to the design of the original version was suitable for school-age children.

To know whether the questionnaire is applicable to be used among Malaysian children, the researcher had done a pilot test on 20 children from a preschool. The result gained for the 15 items of Modified Prosocial Behaviour Questionnaire is highly reliable $(\alpha=.94)$. In knowing whether the content of the storybooks actually measuring the items in the Modified Prosocial Behaviour Questionnaire, two raters were involved in rating the relatedness between the instruments. If "Yes", it is scored as 2 while "No" is scored as 1 . The final result is calculated using the percentage agreement in which $80 \%$ of agreement has been achieved. This indicates that there is a high percentage that the storybooks actually measuring the items. The instructional design that is used in conducting the whole research is the ADDIE model. Aldoobie (2015) stated that the ADDIE model is used in producing an effective design. It is an approach that guides instructional designers, content's developer and teachers in creating an efficient, effective teaching design by applying the processes of the ADDIE model on the instructional product.

\section{Findings and Discussions}

The analysis in this section of the article discusses the objectives achieved. Findings are supported with previous researches' statements.

\section{State of Prosocial Behaviour Before Reading the Improved Story Books}

The mean score of the children's state of prosocial behaviour during the pre-test on the controlled group $(\mathrm{M}=32.07, \mathrm{SD}=3.89)$ and on the experimental group $(\mathrm{M}=23.83, \mathrm{SD}=7.33)$ show a slight difference based on the randomly selected participants from three preschools. 
The state of prosocial behaviour before being exposed to the storybooks was developed by many factors. One of them is from the family. Research from Figueiredo and Dias (2012) has proven that children with single parents have more behaviour problems compared to those who have married parents. Parenting style forms a variety of social environments in the children's lives in the home context (Rosli, 2014). The authoritarian style of parenting has been found to have negative effects on children such as becoming rebellious and showing other problematic behaviours. This is due to the unnecessary power control by the parents (Sarwar, 2016). As overly controlled parents determine a child's behaviour in which leading to the negative ones, prosocial behaviour is less likely to be practiced by them. The effective way of parenting is by adopting the authoritative parenting style; a moderate style of parenting. When mothers practice the authoritative parenting style, the children show more prosocial behaviours comparing to those whose parents demonstrate a permissive parenting style (Altay \& Gure, 2012). Basically, effective communication between the parents and the children can be practiced in building a connection with the children's behaviour (Zaman, Arslan, Malik \& Mehmood, 2014). By having good communication, it will be easier for the parents to instill prosocial behaviour among their children.

Ferreira et al. (2016) have found that the father-child relationship and teacher-child relationship are correlated to children's prosocial behaviour. The father-child relationship is built at home while the teacher-child relationship is built through teaching and learning sessions at school. According to Yeung et al. (2001), due to fathers' increasing involvement in family matters and by that the proneness to get involved in play activities with their children could justify the positive effect between the father-child relationship and the children's prosocial behaviour. Ferreira et al. (2016) continued that by enhancing a warm relationship with the children by having close communication with them may benefit the preschool teachers in encouraging their prosocial behaviour (Yeung et al., 2001). Prosocial behaviour is easily observed and enhanced by teachers during lesson time; when the children are working together to do class work, and also during playtime in which various activities that need them to take turns and helping one another in completing a task are involved.

\section{Elements Present in the Quran}

The essential elements of a children's storybook have been determined by literature reviews. Based on the statistic analysis, there are differences in the mean between the pre-tests and the post-tests. Mean on the pre-test from using the original books $(\mathrm{M}=32.07, \mathrm{SD}=3.89)$ is smaller than the post-test $(\mathrm{M}=32.80, \mathrm{SD}=8.57)$. While on the other hand, mean on the pre-test by using the modified version of the storybooks $(\mathrm{M}=23.83, \mathrm{SD}=7.33)$ is smaller compared to the post-test $(\mathrm{M}=32.50, \mathrm{SD}=7.93)$. As reported, the modified storybooks show a greater change in the mean of the children's prosocial behaviour. Therefore, it is proved that the elements from the Quran and the other additional elements do have positive effects on a child's prosocial behaviour.

Table 2: Mean on Pre and Post-Test By Using Original and Modified Books

\begin{tabular}{lllll}
\hline & Test & N & M & SD \\
\hline Original books & Pre & 30 & 32.07 & 3.89 \\
Modified books & Post & 30 & 32.80 & 8.57 \\
& Pre & 30 & 23.83 & 7.33 \\
& Post & 30 & 32.50 & 7.93 \\
\hline
\end{tabular}


The elements that have been chosen from the Quran and have been included in the modified storybooks are narrative, dialogue, repetition and questioning. Other elements included are typography, illustration and simple phrase. The elements were elaborated in the literature review and are believed to be practical and suitable for teachers in delivering the stories and also for the children in understanding and easy to remember to practice the values afterward.

Kabir (2013) in his study stated that there are a number of options in Quranic ways that can be practiced in schools to instill virtues and moral values among students:

a) storytelling (qasas)

b) modelling (qudwah)

c) reward and punishment

d) instruction method

e) questioning method

f) conversation and dialogue

g) repetition method

h) practical demonstration.

Some of the Quranic approaches listed above have been included in the current study and they are proven to be working in conveying the moral value through storybooks.

\section{Effects of the Improved Story Books on Prosocial Behaviour}

This study has proven that there is a significant effect of the modified version of the storybooks in which contain the elements chosen from the Quran on a child's prosocial behaviour; $\mathrm{t}(29)=$ $-16.478, p=0.000$. The improvements by including narratives, dialogues, repetitions and questions have definitely helped in instilling the positive value among children.

Table 3: Paired Sample T-Test Analysis

\begin{tabular}{lllllc}
\hline & $\mathrm{M}$ & $\mathrm{SD}$ & $\mathrm{t}$ & $\mathrm{df}$ & $\mathrm{Sig}(2$ tailed $)$ \\
\hline Original books & -0.73 & 9.40 & -0.43 & 29 & 0.67 \\
Modified books & 32.80 & 8.57 & -16.48 & 29 & 0.00
\end{tabular}

A paired sample t-test was conducted to compare pre and post-test when reading the original version of the storybooks and also the modified version of the storybooks. There was no significant difference on the pre-test $(M=32.07, S D=3.89)$ and post-test $(M=32.80, S D=8.57)$ when using the original books; $\mathrm{t}(29)=-0.427, \mathrm{p}=0.672$ On the other hand, there was a significant difference on the pretest $(\mathrm{M}=23.83, \mathrm{SD}=7.33)$ and post-test $(\mathrm{M}-32.50, \mathrm{SD}=7.93)$ when using the modified books; $\mathrm{t}(29)=-16.478, \mathrm{p}=0.000$.

Edward Nawotka, an Editor-in-Chief from Publishing Perspective had stated the meaning of "great" as sheer excitement of having adoration on a book (Abrams, 2012). The characteristics of a great book were elaborated by the President and CEO of Scholastic Inc., Richard Robinson.

Some of the characteristics are:

a) a book that includes a simplified and authentic idea with great power and precision 
b) a book which builds a connection with the person reading it, citing its story into the mind of the readers

c) a book that makes the world look larger and extra amusing

d) a book that gives an understanding of an entire but distinct world (Abrams, 2012).

Elements adapted from the Quran are meant to create an effective book for children. By simplified the words and phrases, children could easily understand the stories better and easier. The modified story books definitely have to build a connection with the reader. This has been proven by children showing the remembrance of the moral values learned and applying them in real life. The modified books help in giving a picture of the world and understanding of the different parts of it. As the stories tell about life during the prophets' time, the ideas of how people at those times behaved and interacted are pictured in the stories. Therefore, children could have more examples of building their own characters.

\section{Conclusion}

It is reported that there are differences in the pretest and post test scores obtained. There is no significant difference in the prosocial behaviour among children in the controlled group in which were presented with the original version of the selected storybooks. On the other hand, there is a significant difference in prosocial behaviour among children in the experimental group that was presented with the modified version of storybooks. Therefore, it is proven that the elements from the Quran are effective in implementing prosocial behaviour among children through reading story books.

It is suggested that involving more preschools in this type of research in the future. This is due to the different approaches that preschools are applying in Malaysia. This may affect the behaviour learning among children including prosocial behaviour. Another aspect that needs to be focused on is the language being used. As the current storybooks are using Bahasa Malaysia, it might be impossible for Muslim children in international preschools to understand. This can also be applied to preschools that are using English as their medium of communication. Therefore, the English version of storybooks may be considered in an attempt to study among different participants with different backgrounds.

\section{References}

Abrams, D. (2012, June 1). What makes a children's book great? we have some answers. Retrieved January 28, 2019, from https://publishingperspectives.com/2012/06/what-makes-a-childrens-book-great- wehave-some-answers/

Ahmed Abba, S. (2014, December 12). Youth immorality: Who is to blame? Retrieved July 7, 2018, from http://www.peoplesdailyng.com/youth-immorality-who-is-toblame/

Al-Bar, M., \& Chamsi-Pasha, H. (2015). The sources of common principles of morality and ethics in islam. Contemporary Bioethics. doi: file:///D:/JOURNALS/Islamic theories.pdf

Aldoobie, N. (2015). Addie model. American International Journal of Contemporary Research, 5(6). doi: file:///D:/JOURNALS/ADDIE.pdf

Al-Khalediy, K. (2011). Education and methods of teaching in islam in the era of az-zarnooji. doi: file:///D:/JOURNALS/2. Islamic View/2011 Journal Education era Az-Zarnooji.pdf

Teaching 
Almenoar, L. (2014). Hots using quranic verses in english. International Journal of Managerial Studies and Research, 2(6). doi: file:///D:/JOURNALS/7.

Questioning/2014 Journal Hots Using Quranic.pdf

Al-Somadi, M.M.F. (2012). The effect of a story-based programme on developing moral values at the kindergarten stage. Interdisciplinary Journal of Contemporary Research in Business, 4(7), 534-559.

Ashaari, M. (2011). An assessment of teaching and learning methodology in Islamic studies. Procedia - Social and Behavioral Sciences. doi: file:///D:/JOURNALS/2. Islamic View/2011 Journal Teaching \& Learning.pdf

Bay, D., \& K.Hartman, D. (2015). Teachers asking questions in preschool. International Journal of Humanities and Social Science, 5(7). doi: Questioning/2015 Teachers Asking Preschools.pdf

Carlo, G., \& Randall, B. A. (2002). The development of a measure of prosocial behaviors for late adolescents. Journal of Youth and Adolescence,31(1), 31-44. doi: https://link.springer.com/article/10.1023/A:1014033032440

Cherry, K. (2017, June 21). The basics of prosocial behavior. Retrieved January 3, 2018, from https://www.verywellmind.com/what-is-prosocial-behavior-2795479

Children's experiences with nursery rhymes promote early phonological and print related skills development. (2013). Center for Early Literacy Learning, $\quad 3(1)$ doi: file:///D:/JOURNALS/6. Rhymes \& repetition/2013 Article Experience with Nursery Rhymes.pdf

El-Tahry, N. (2010). Textual integrity and coherence in the qur'an: Repetition and narrative structure in surat al-baqara. doi: file:///D:/JOURNALS/6. Rhymes \& repitition/2010 Journal Repetition in Surat al-Baqara.pdf

Ferreira, T., Cadima, J., Matias, M., Vieira, J. M., Leal, T., \& Matos, P. M. (2016). Preschool children's prosocial behavior: The role of mother-child, father-child and teacher-child relationships. Journal of Child and Family Studies. doi: https://www.researchgate.net/publication/292386190_Preschool_Children's_Prosocial _Behavior_The_Role_of_Mother-Child_Father-Child_and_TeacherChild_Relationships

Figueiredo, C. R., \& Dias, F. V. (2012). Families: Influences in children's development and Behaviour, From Parents and Teachers' Point of View. David Publishing,2(12), 702-714.

Kabir, A. I. (2013). The qur'ānic approach to the inculcation of moral values: Patterns for teacher education. International Journal of Quranic,5(2), 15-32. doi: http://ejum.fsktm.um.edu.my/article/1455.pdf

Khan, S. (Ed.). (2017). Kisah teladan daripada rasulullah. Darul Mughni.

Knafo, A., Israel, S., \& Ebstein, R. (2011). Heritability of children's prosocial behaviour and differential susceptibility to parenting by variation in the dopamine receptor D4 gene. Development and Psychopathology, 23, 53-67.

Lee., K., Talwar, V., McCarthy, A., Ross, I., Evans, A., \& Arruda, C. (2014). Can classic moral stories promote honesty in children? 1-21.

McLeod, S. (2015). Piaget's theory of moral development. Retrieved December 8, 2017, from https://www.simplypsychology.org/piaget-moral.html

Meibauer, B., \& Meibauer, J. (2013). Towards a cognitive theory of picture books. International Research in Children's Literature, 143-160. doi: Illustration/2013 Towards a Cognitive Theory of Picturebooks.pdf

Mohd Taib, M., Alias, A., \& Mohd Taib, M. (2011). Social psychology: A critical analysis from islamic and scientific perspectives and application in industrial/organizational 
psychology. doi: http://religiondocbox.com/Islam/65981566-Social-psychology-acritical-analysis-from-islamic-and-scientific-perspectives-and-application-in-industrial organizational-psychology.html

Nicholas, J. (2007). An exploration of the impact of picture book illustrations on the comprehension skills and vocabulary development of emergent readers. doi: file:///D:/JOURNALS/9. Illustration/2007 Article Impact of Illustrations on Comprehension Skill.pdf

O'Grady, W. (2007). How children learn language - what every parent should know. doi: file:///D:/JOURNALS/7. Questioning/bahasa mudah 3.pdf

Rahim, H., \& Rahiem, M. D. H. (2012). The use of stories as moral education for young children. International Journal of Social Science and Humanity, 2(6), 454-458.

Rosli, N. A. (2014). Effect of parenting styles on children 's emotional and behavioral problems among different ethnicities of muslim children in the u.s. $E$ Publications@Marquette.

Sarwar, S. (2016). Influence of parenting style on children's behaviour. Journal of Education and Educational Development,3(2), 222-249. doi: https://www.researchgate.net/publication/311451184_Influence_of_Parenting_Style_o n_Children's_Behaviour

Subramaniam, V. (2000). Pemerolehan bahasa di kalangan kanak-kanak melayu. doi: file:///D:/JOURNALS/7. Questioning/bahasa mudah1.pdf

Vale, E. (2000). Factors contributing to prosocial behavior among pre-school children from low-income families. doi: file:///D:/JOURNALS/modified prosocial behavior instrument.pdf

Wentzel, K. (2015). Prosocial behaviour and schooling. Encyclopedia on Early Childhood Development, 1-5.

Zaman, R., Arslan, M., Malik, R. K., \& Mehmood, A. (2014). Effect of parenting style on child behavior: A qualitative analysis. Journal of Education and Practice,5(26), 112-118. doi: https://www.researchgate.net/publication/266384152_Effect_of_Parenting_Style_on_ Child_Behavior_A_Qualitative_Analysis

Zarasi, M., \& Ramchahi, A. (2014). Dialogue between allah and iblīs in the qur'ān: Structure and characteristics. Centre of Quranic Research. doi: file:///D:/JOURNALS/4.Dialogue/2014 Journal Dialogue between Allah n Iblis.pdf 